\title{
Enlightenment of Locke's Moral Education Thought to the Moral Education of Chinese Secondary Vocational School Students
}

\author{
Peng Zhang, ${ }^{1}$ Yanna Feng ${ }^{2}$ \\ ${ }^{1}$ College of Applied Science of Technology, Beijing Union University, Beijing100101, China \\ ${ }^{2}$ Teachers College, Beijing Union University, Beijing100101, China
}

\begin{abstract}
In recent years, as China attaches increasingly attention to moral education in vocational education schools, the problems in the moral education in secondary vocational schools, such as bad conduct of students, ineffective teaching of teachers and weak cooperation between home and school, have been gradually exposed. These problems have posed challenges to the moral education in secondary schools. Locke is a famous English educator in the 17th century. His educational thoughts are reflected in Some Thoughts Concerning Education, and his moral education thought occupies the main part of this book. The effective experiences of Locke's moral education thought in family education, teachers' morality, children's discipline and educational environment have significant implications for the current moral education of secondary vocational schools in China.
\end{abstract}

Keywords: Locke, Moral education, Secondary vocational school.

\section{Introduction}

In 1684 Locke, who was in exile in the Netherlands, was asked by his relative Edward Clark to instruct him in the education of his son, with whom he corresponded for several years[1]. In the series of letters, Locke taught and communicated his educational experience to Clark. Later, Locke sorted out the letters and published them officially in 1683 as Some Thoughts Concerning Education. The main content Locke expressed in this book was gentleman education. The theory of gentleman education discussed by Locke in Some Thoughts Concerning Education is divided into three parts: physical education, moral education and intellectual education. Moral education is the main content of gentleman education and occupies the main part of this book. Vocational school graduates are the mainstay of the future society, the ideological and moral status of these students is directly related to the quality of the industrial army, but also related to the future of the country and the nation. Therefore, strengthening the ideological and moral education of secondary vocational students is not only the objective requirement of improving the ideological and moral quality of secondary vocational students, but also the objective requirement of improving the quality of social workers and cultivating qualified workers.

\section{Locke's Thought of Moral Education}

Locke divides education into physical education, moral education and intellectual education. Locke himself attached great importance to moral education, believing that moral education is the most important education for a person[2]. He once mentioned in his book that only with good self-cultivation, sound body and extensive knowledge can a person be properly used. This paper summarizes Locke's moral thought as follows.

\subsection{The Importance of Family Education}

The school of Locke's time had begun to implement the class teaching system, and it was difficult for school teachers to cultivate every student in the class into a person with good moral cultivation. But in the family, parents can carry out adequate moral education for their children. Therefore, Locke believes that family education plays a crucial role in the process of moral education for children. Regarding family education, Locke proposed the following educational concepts. First, Locke believed that parents should show their children enough respect. Children are independent-minded individuals and should be respected by their parents. Moreover, due to their young age and immature psychology, if children are not respected, the strict teaching and criticism of their parents are easy to produce rebellious psychology, which is not conducive to children's physical and mental development. Second, Locke believed that parents should set an example for their children. Children are best at imitating other people's behavior, and parents are the people who have the most contact with children every day, so it is inevitable for parents to become the object of children's imitation. Therefore, parents should strictly regulate their words and deeds. If they do not want children to say or do, parents themselves must not do it in the presence of their children. If a child does something that is considered a mistake, but the parents do it. Then the child will use the parents' example as an excuse to continue to do it, and it is too late to correct it. In addition, parents should never use adults as an excuse to do something wrong, because such an excuse is likely to make children rebellious and more willing to imitate their parents' wrong behaviors[3].

\subsection{Some Requirements for Teachers}

Locke believed that teachers play a vital role in the development of children, and the quality of teachers determines the development of children. In his Some Thoughts Concerning Education, Locke proposed that a teacher should have the following requirements. First of all, a teacher must be well educated and understand etiquette. No matter when, where and what kind of people he is dealing with, 
he should have proper manners and politeness. Locke believed that only with the help of teachers can students develop well in the future, in addition, a well-educated student will be easier to make friends in the future development process. Second, apart from good breeding, teachers should distinguish between truth and falsehood. Teachers should teach their students how to tell whether a person is of high moral character, to approach those who are of high moral character, and to stay away from those who are of low moral character. Thirdly, Locke believes that not everyone needs to have a wide range of knowledge, but everyone should have a good upbringing, so teachers should put moral education first and intellectual education second in the process of teaching students. Teachers themselves should be good imitation objects for students to appreciate their words and deeds and take the initiative to imitate. And teachers also need to encourage students in time after imitation, and give students the motivation to continue imitation and develop good morality.

\subsection{Be Cautious about the Discipline and Punishment of Children}

Locke believes that when children make mistakes, parents and teachers should hold a calm and rational state of mind and cautiously discipline and punish children. First of all, children by nature yearn for freedom, so parents and teachers should never impose learning on children in the form of tasks. A child may initially enjoy learning, but as soon as it becomes a task to be done, the child immediately develops an aversion to it. Second, parents and teachers should be good at observing children's interests and exploring students' talents, and try to let children learn what they like because because children are most effective at learning what they like. Third, according to reinforcement theory, rewards and punishments play an important role in children's behavior education, but improper external rewards and punishments will also damage children's internal motivation, making rewards and punishments ineffective. Therefore, Locke pointed out that punishment for children should be combined with shame of children to make punishment meaningful. All children have a sense of shame, and shame is the best tool to help children correct their mistakes. The punishment of parents and teachers should enable children to admit their mistakes from the heart and feel ashamed of their mistakes, so that they can take the initiative to correct their mistakes. Fourth, Locke opposes corporal punishment and believes that children must not be corporal punished unless they persist in repeated education.

\subsection{The Importance of Environment for the Cultivation of Children's Morality}

Learning environment refers to the external environment that affects children's learning, which has a deep-rooted impact on the cultivation of children's virtue. Locke put forward the following points about the importance of learning environment in Some Thoughts Concerning Education. First of all, Locke believed that students should learn and grow up in a healthy environment. Some students in school did not have good cultivation, and children learning in such an environment which is not conducive to their own development is bound to imitate some bad behavior. Locke, therefore, did not advocate sending children to school. Instead, he advocated having private tutors teach them at home. Second, rich families in Locke's time all employed servants, and Locke advocated keeping children away from servants because servants are willing to please and flatter children. Whether children's actions are correct or not, servants will blindly support them, making children gradually become arrogant and complacent, which is not conducive to children's development. Third, children are good at imitating. Children often learn many improper words, tricks and bad habits from servants who are ill bred or morally corrupt. Therefore, Locke believed that families with conditions should try their best to hire governesses and strictly select servants, and strictly regulate their words and deeds.

\section{Problems Existing in Moral Education of Secondary Vocational Schools in China}

Nowadays, with the development of society, there are more and more new ideas and concepts which continue to impact people's moral concepts and spiritual world. For secondary vocational students in the period of value formation, the emerging new ideas and concepts are easy to cause their anomie, which challenges the moral education in secondary vocational schools.

\subsection{Some Students have Bad Conduct}

At present, there are many students with bad conduct in secondary vocational schools in China, and the proportion of these students is higher than that in ordinary high schools[4]. Some students have lax discipline and do some things against school rules, including coming to school late and leaving early, bringing entertainment equipment into the classroom, smoking in the school and so on. In addition, some students abused their classmates and disrespected teachers on campus. What's more, they organized campus bullying and fighting on campus, which had an extremely serious adverse impact on the school and society.

\subsection{Some Teachers have Problems with their Education}

On the one hand, some secondary vocational teachers have no good self-cultivation and are not responsible for the work of student. They do not work hard in school, do not pay attention to regulating their words and deeds, and do not have the concept of lifelong learning, so they can not set a good example for students. Students are good at imitating their teachers. If teachers can't establish good cultivation, it's almost impossible for students to have good cultivation. On the other hand, many teachers lack correct education methods and ideas. Some teachers blindly accuse and punish students without asking questions after students make mistakes. And some teachers even make sarcasm and satire on students, causing harm to students' hearts. Such teachers can not actively guide students, but estrange from students and destroy the relationship between teachers and students. Such teachers are unable to help students correct their mistakes. Instead, they become estranged from students and destroy the relationship between teachers and students.

\subsection{The Relationship Between Home and School is not Harmonious}


Moral education in secondary vocational schools should be carried out under the joint efforts of parents and teachers, but at present many secondary vocational schools ignore the importance of family education and fail to establish a good home-school cooperative relationship. Some studies have pointed out that the attitude and way in which schools accept parents to participate in school education will directly affect parents' participation in home school cooperation, and then affect the effect of home school interaction[5]. In home-school interaction, many schools often ignore the principal role of parents, and just regard them as participants or even bystanders in home-school cooperation[6]. Many secondary vocational teachers do not take the initiative to communicate with their parents about their students' situation, nor are they willing to communicate with their parents, which greatly reduces the effectiveness of home school cooperation. In addition, some schools do not take the initiative to understand the family background of students, the basic situation of parents and the planning and expectation of students' development, resulting in conflicts in home school cooperation.

\section{Enlightenment to the Moral Education of Chinese Secondary Vocational School Students}

As introduced in the third paragraph, there are still some problems in China's secondary vocational moral education at present, and some of Locke's moral education thoughts have important enlightenment to the moral education of secondary vocational schools in China. Therefore, we summarize the implications in the following four points.

\subsection{Promote Home-school Cooperation and Attach Importance to Family Education}

Locke emphasized the importance of family education to moral education in Some Thoughts Concerning Education. However, at present, there is little communication between secondary vocational schools and students' parents in China, which is easy to lead to differences in the cultivation goals of school and family. In addition, many parents do not understand educational ideas and methods, which is easy to mislead their children and make them form bad moral habits. Therefore, secondary vocational schools should actively promote the establishment of home school cooperation and promote the positive role of family education in students' moral education. First, secondary vocational schools should encourage teachers to communicate with students' parents frequently by telephone or meeting, jointly develop students' moral education training plans, and establish harmonious cooperative relations with parents. Second, secondary vocational schools can organize regular parents' meetings. In addition to exchanging the current situation of students in their classes, they should focus on giving lectures on education topics to parents, teaching them educational ideas and methods, and emphasizing the importance of setting an example to parents because only when parents have good virtue, children can have good virtue. Third, schools should often emphasize to students the importance of communicating with their parents and encourage students to communicate with their parents when they encounter problems.

\subsection{Convince People with Virtue and Cultivate Teachers'} Good Morality

During the several years of secondary vocational students studying in school, teachers spend more time with them than their parents, and students are good at imitating teachers' behavior. Therefore, the teacher's own good moral cultivation is the premise of his moral education for students. At present, many secondary vocational teachers in China have neglected the importance of their own exemplary role, and they are unable to abide by the moral education requirements issued by their students, which leads to a stronger rebellious psychology among students. Thus secondary vocational schools should strengthen the moral education work for teachers, strictly manage the teaching staff, and seriously deal with teachers' anomie behavior. First, secondary vocational schools can carry out regular moral education lectures, moral education talks and other related work for teachers, and emphasize to teachers the importance of abiding by moral standards. Second, secondary vocational schools should improve the management norms of teachers' moral behavior, strengthen the inspection mechanism for teachers' behavior, and organize moral education life meetings on a regular basis to increase teachers' self-criticism and mutual criticism. Third, schools should take teachers' misconduct seriously, regularly organize teachers to study teachers' moral education norms and regulations, and retain veto power for teachers with moral corruption.

\subsection{Put People First and Standardize Teachers' Moral Education Methods}

At present, many secondary vocational teachers lack reasonable methods to carry out moral education to secondary vocational students, which can not effectively help students to correct bad habits and shape good moral norms, but also cause students' rebellious psychology, and do not cooperate with the school's moral education work. The basic problem of education is human development and human education, that is, how to implement educational activities to promote human development. Therefore, teachers should also implement the educational concept of putting people first in the moral education of secondary vocational students[7]. First, teachers should regularly communicate with students and their parents, and visit their families when necessary to understand each student's personality and living habits, so as to teach students according to their aptitude and adopt different means of moral education according to their personality. Secondly, teachers should care for students and establish a good teacher-student relationship with them[8]. When conducting moral education to students, they should look at problems from the standpoint of students, try to treat each student with a gentle attitude and avoid harsh criticism and corporal punishment. Third, when correcting students' bad moral habits, teachers should enlighten them with affection and motivate them with reason, so that students can take the initiative to correct their mistakes.

\subsection{Standardize Management and Create A Good Learning Environment}

The importance of the learning environment to the moral education of secondary vocational students is self-evident. If 
the majority of students in a class do not have good moral standards, then the students in the class who do not have bad habits are also easily influenced and infected with bad habits. Locke emphasized that the learning environment is an external environment that affects children's learning and has a deep-rooted impact on the development of children's morality. Therefore, secondary vocational schools should strive to create a good learning environment for students. First, schools should hold regular lectures on moral education to emphasize the moral code and make students keep it in mind. Second, schools can strengthen the management mechanism of students' ethics, elect a moral education monitor in each class, and the moral education monitor will coordinate with other class cadres and class teachers to manage and restrain the behavior of the students in this class. Third, secondary vocational schools can practice the moral education evaluation system, and evaluate from low to high to encourage students to abide by the code of ethics for students. Schools can divide the class into multiple moral education groups, and conduct moral education evaluations within the class; it can also select the class as a unit to select excellent moral education classes in the school.

\section{Reference}

[1] Hu Junjin. Revolutionary Prometheus: The gentleman and his education in Locke's some thoughts concerning education[J]. Journal of Educational Studies, 2021, 17(05): 3-16.

[2] Qin Hua. A history of education full of philosophy-reading some thoughts concerning education[J]. Education and Vocation, 2010(07):108.

[3] Locke J. Some thoughts concerning education[M]. CUP Archive, 1887.

[4] Sun Aijun. Analysis of the current situation of moral education and educational countermeasures for secondary vocational students [D]. Ludong University, 2013.

[5] Yu Qinfang. The cognitive differences between principals and parents in home-school cooperation: Based on a survey of 146 public schools in Shanghai[J]. Journal of Shanghai Educational Research, 2014(05): 42-45.

[6] Bian Yufang, Zhou Xinran. Cause analysis and countermeasure research on poor home-school interaction $[\mathrm{J}]$. Journal of the Chinese Society of Education, 2019(11): 39-44.

[7] Xiong Ying, Yang Xiaoli. The enlightenment of moral-education thought in Locke's some thoughts concerning education on the moral education of normal school students[J]. Theory and Practice of Contemporary Education, 2020, 40(18): 38-40.

[8] Wang Qian. "Three Keys" and enlightenment of Locke's teaching method[J]. Journal of Teaching and Management, 2016(15): 4-6.

\section{Author Profile}

Peng Zhang A master student at the College of Applied Science and Technology of Beijing Union University, majoring in vocational and technical education.
Yanna Feng Associate professor and master tutor of the Teachers College of Beijing Union University, whose research direction is intelligent information control and vocational and technical education. 